\title{
Features of Value Added Distribution of Gazprom Corporation in 2004-2012
}

\author{
Assoc. Prof. Dr. Dmitri Pletnev (Chelyabinsk State University, Russia) \\ Assoc. Prof. Dr. Ekaterina Nikolaeva (Chelyabinsk State University, Russia) \\ Zinfira Bitkulova (Chelyabinsk State University, Russia)
}

\begin{abstract}
Searching for new indices of a modern corporation is one of urgent problems of modern economic science. In our opinion, there are good prospects of using "a value added" as an indicator. It reflects a corporation's ability of creating a new value, whereas its distribution between different players shows an ability of meeting their interests. The aim of the present paper is to propose a methodology and consider a calculation of the amount and distribution of values added between major groups of players on the basis of some financial statements of the Gazprom Corporation for the period of 2004-2012. The proposed methodology for estimating a value added is based on a Marxist interpretation of this concept. Such a value added can be calculated as a sum of elements that belong to different stakeholders. For our calculation, we have used data contained in the Gazprom Corporation's IFRS consolidated financial statements and quarterly reports for the period of 2004-2012. The main part of the value added of Gazprom was appropriated by the state through tax and customs systems. Its share is around $50 \%$ of the total value added. The second most important recipients of the value added are corporation owners. Their share just slightly fell short of $40 \%$ in 2010 and 2011, and in 2012 it was $33.8 \%$. The third most important subjects in terms of value added assignments are workers. Their share has been steadily shrinking in the period from $2004(13.8 \%)$ to $2012(10.4 \%)$.
\end{abstract}

\section{Introduction}

In modern economic science, a discussion concerning the assessment of results of economic activity is going on. This problem is considered as one of central by experts of the World Economic Association - WEA, among which are J. Stiglitz, A. Sen and J.-P. Fitoussi (Stiglitz, Sen and Fitoussi, 2009). On the one hand, the criticism of macroeconomic indices, of a gross domestic product and other indicators of SNA [system of national accounts] becomes a banality. And various techniques of measuring "wellbeing" and "happiness" are offered to "support" the indices. At the microeconomic level itself, the existing system of assessing the efficiency of enterprises" activity, based on the simultaneous use of accounting and stock market data, is challenged. The first group of data is blamed for their "controllability", whereas the second one - by way of contrast - is critisised for its poor connection with a real situation. However, in our opinion, an inadequacy of the main indicators is yet a bigger problem. They are frequently employed by analysts, authorities and scientific community for assessing the overall performance of corporations. First of all, profit is at stake. Without going into details of contradictions of assessing profit as one of major economic categories, we will note that inherently it only gives some information regarding a corporation's activity efficiency - for the owners. All other concerned groups - managing directors, employees, the state, investors, suppliers, etc., even in case of a high profit may fail to satisfy their interests and expectations associated with the corporation. And a modern evaluation of the efficiency of a corporation has to consider not only interests of the owners, but also those of other stakeholders.

In these conditions, there arises a topical problem of a search for other more adequate index assessing a corporation. In our opinion, "a value added" shows some good prospects as an indicator. It reflects the ability of a corporation to create a new value, while the latter's distribution between various entities represents the ability to satisfy their interests. The purpose of the present work is to offer a methodology and consider the calculation of the size and distribution of a value added between major groups of entities by the example of the Gazprom Corporation's data for the period of 2004-2012.

\section{Data and Methodology}

The offered methodology of assessing the size of a value added is based on Marx's treatment of this concept as "newly created value" (for more details please see Pletnev, 2013). This attitude differs from the so-called "concept of an economic value added" gaining popularity, which has in reality little in common with a value added in its canonical understanding and which diverts one from the real range of problems to derivatives and particulars which only interest owners of corporations.

The value added thus understood can be calculated quite simply: as a difference between a sales revenue and material costs. However, in our opinion, it is more correct to calculate it as a sum of elements relating to various concerned entities. According to some reporting data (in the event of the JSC Gazprom it is a question of consolidated financial statements prepared according to IFRS (a regime of access to reporting data at the official website of the Company, Gazprom 2013a) and of a quarterly report of the Emitter for the 1-st quarter of the 
subsequent year (the 1-st quarter of 2013 is available at the address, Gazprom 2013b), an assessment of elements of a value added at the disposal of various entities was carried out: concerning owners (a net profit, from a report on a total revenue in a IFRS consolidated statement), concerning employees (expenses on remuneration of labour, from the Note No. 26 to the IFRS consolidated statements), concerning managing directors (remunerations to members of the Board of Directors and those of the management, from Item 5.3 of a quarterly report of the Emitter), concerning the state (paid taxes, including those at the expense of employees, from Note No. 30 to the IFRS consolidated statements), concerning investors (the paid rate of interest from Note No. 27 to IFRS consolidated statements). And a sum of these elements forms the size of the Gazprom Corporation's gross value added.

\section{Results}

The gross value added of the JSC Gazprom shows steady positive dynamics. In the whole period considered it increased by 4.5 times and made 3580.2 billion rubles or $75.2 \%$ in 2012 . Such a high share of a value added is explained by the character of the production activity of the Gazprom Corporation: because this is an instance of an extractive company, a value added is created due to the very fact of the production (extraction) and sale of extracted raw materials, i.e. natural gas. In this regard, there are still reserves for increasing the share of the value added: Gazprom have not yet been allowed to realize their product at retail in foreign markets, also there is a potential of the growth of the value added in the sphere of the high-level processing of natural gas. However, the share of the value added in the sales revenue of the Gazprom Corporation reduced from maximum $87.2 \%$ in 2006 to $75.2 \%$ in 2012 in the considered period (Fig. 1).

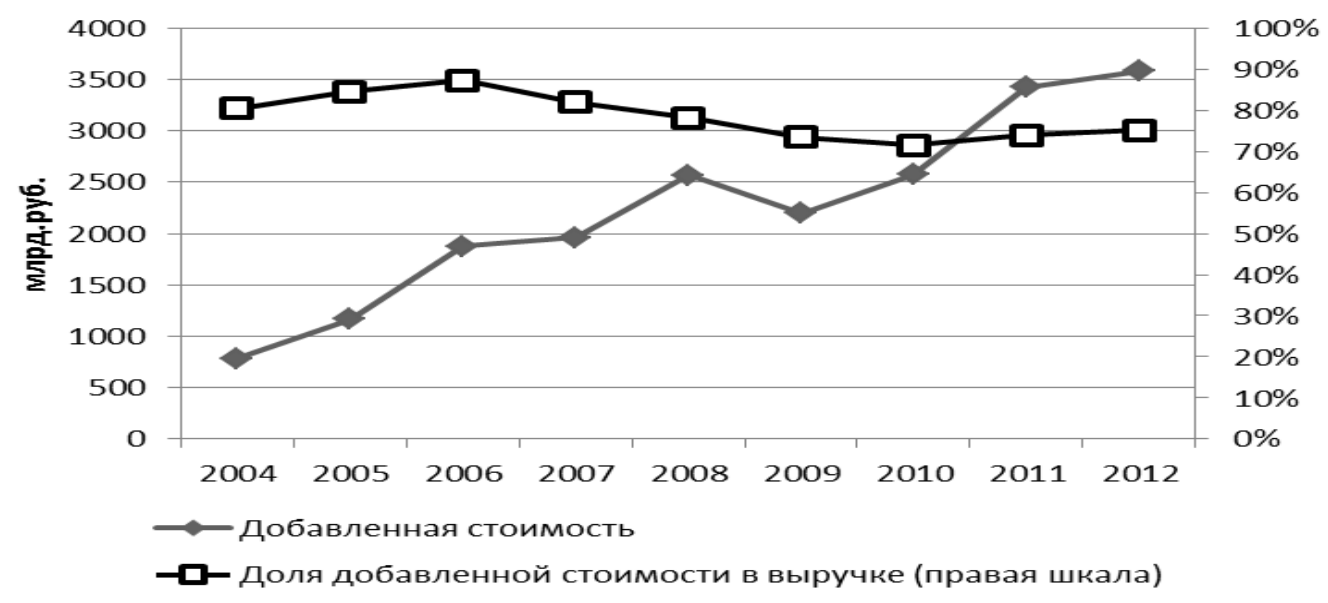

Figure 1. The dynamics of the gross value added and the share of the value added in the Gazprom Corporation's revenue in 2004-2012

A detailed analysis of the structure of the value added has demonstrated that different parts of this value added falls to the share of its various entities (owners, the state, employees, managing directors, and investors). There has been obtained the following distribution of the value added with the Gazprom Corporation in 2004-2012 (Fig. 2)

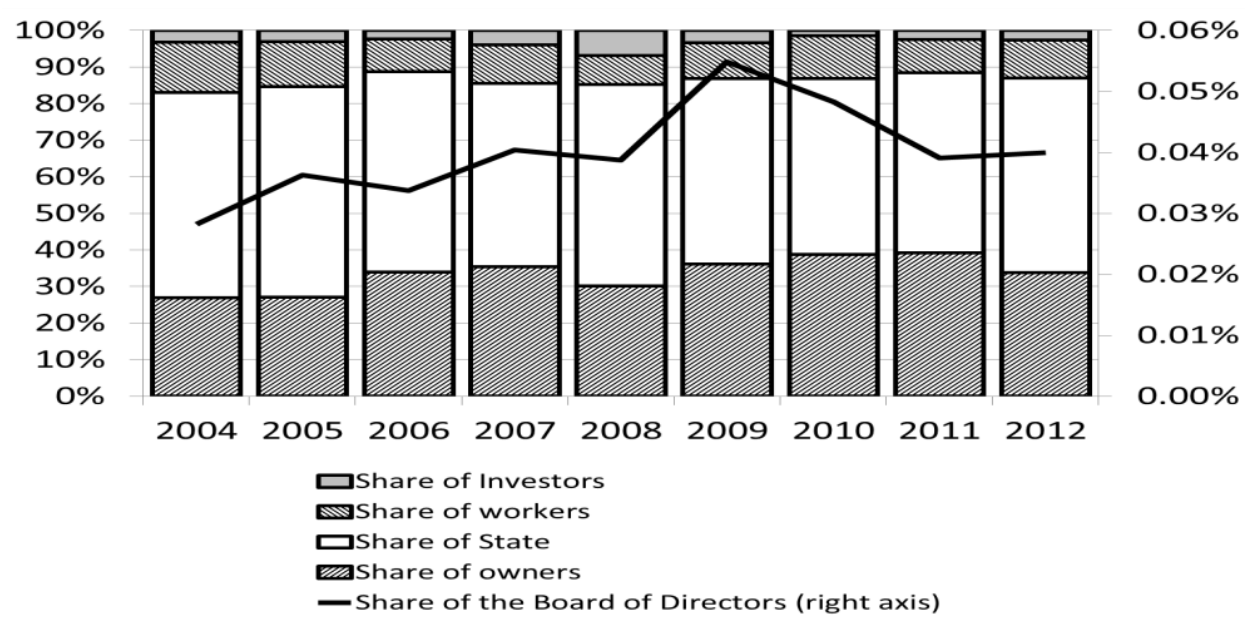

Figure 2. A distribution of the value added of the Gazprom Corporation between major entities 
The main part of the value added of the Gazprom Corporation, which belongs (for the most part) to the state, is appropriated by the latter by means of the tax and customs system (the share fluctuates around 50\% of the whole value added), as well as through insurance premiums in the system of social insurance (earlier it was a unified social tax payment). Mainly, this takes place at the expense of customs payments, a severance tax and a value added tax (up to two thirds of the whole sum of taxes and customs payments). In absolute expression, the state received 10.47 trillion rubles from Gazprom - about 38\% of the latter's consolidated revenues - in 2004-2012, i. e. about half of the whole created value added. And in this sense, Gazprom may certainly be called "a national property". In absolute expression, both the total amount of taxes and the sum of their separate types is steadily growing, the basic growth rate making 4.32, which corresponds approximately to a 20-percent average annual growth. At the same time, the revenue has been growing by $21.9 \%$ on an average yearly, whereas the value added has been increasing by $20.8 \%$. Therefore, in relative terms - and this is confirmed by the further analysis the share of the state is but insignificantly reducing. At the same time, a growth of the share of the state was observed in 2011-2012, which may signalise the beginning of a new tendency.

The dynamics of the structure of the Gazprom Corporation's tax burden can be observed in Fig. 3. As it is obvious from the figure, the state receives the major part of the value added through indirect taxation, i.e. these taxes are factually paid by consumers. It is a question of customs payments, a value-added tax and excise taxes (up to 35 percent of the value added, up to 70 percent of the whole tax burden). Also, a considerable part is made by a severance tax - a peculiar form of acquiring a land rent. In the figure, the latter tax "is embedded" in other taxes, making up to $80 \%$ in this group, and up to $23 \%$ of the whole tax burden. Also, along with the severance tax, this group includes a property tax, but its share in all paid taxes is insignificant - about 3.5\%. A share of taxes paid "for employees" is also insignificant - this concerns an individual income tax and the payment of social contributions (this part approached $3 \%$ of the size of the value added by the end of the considered period or a little more than $6 \%$ of the share paid to the state). A profit tax, as contrary to a general opinion, does not occupy a considerable share in the total amount of the value added (in 2012 it was $7.9 \%$ ). At the same time, the total amount of the paid profit tax is considerable - 301 milliard rubles. It may be noted that financial statements only disclose obvious contributions to the advantage of the state, alongside with that the Corporation itself was repeatedly used for political goals when various countries were periodically granted discounts for the gas, which were motivated by "political policy". A short-received income due to such actions may also be considered as a share of a "virtual" value added which is received by the state in the form of political capital. However, evaluations of such an income are a subject of a separate investigation. Also, we consider it important to emphasise that a considerable share of tax payments of the Gazprom Corporation may be invisible for the majority of researchers - a profit tax is only reflected in the traditional forms.

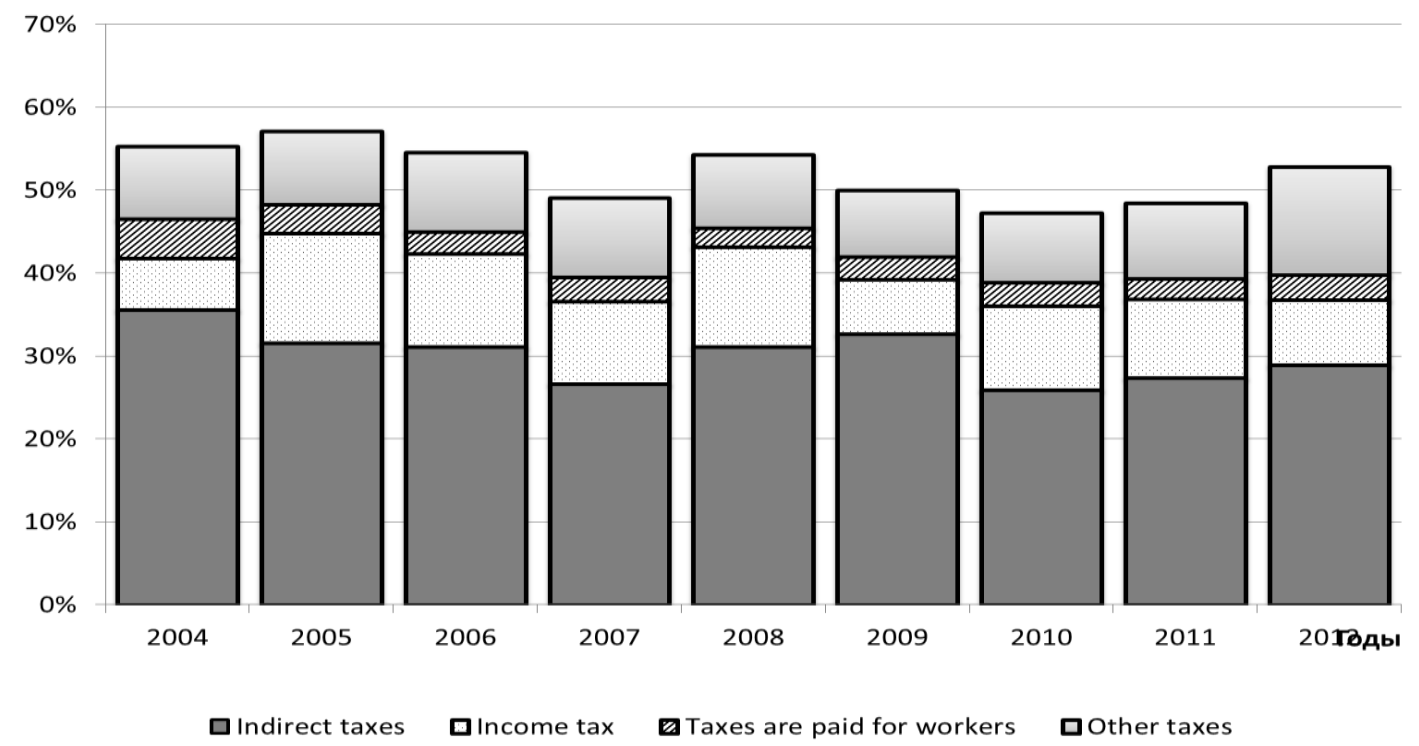

Figure 3. The dynamics of the structure of the share of the Gazprom Corporation's value added, allocated to the advantage of the state in 2004-2012

In more detail, the structure of the value added, which is at the disposal of the state, is presented according to types of taxes and payments in Fig. 4 (2004) and Fig. 5 (2012). It may be seen from the diagram, that the main share is occupied by customs payments (in $2004-42 \%$, in $2012-36 \%$ ), a share of VAT remained almost invariable $-15 \%$ in 2004 and $13 \%$ in 2012. A profit tax share increased from 11 to $15 \%$ and a severance tax share grew up from 13 to $22 \%$. The last change is connected with an increase of a taxation rate, while the profit tax rate, on the contrary, decreased from 24 to $20 \%$. Therefore, the growth of the share of this tax 
(simultaneously, the absolute sum of the tax has also increased) may be explained by an essential growth of its base, that is to say, of profit. Changes in the share of other payments of the value added in favour of the state do not look considerable. Thus, the share of the state in the structure of the value added, if one speaks merely about taxes and customs payments, maintains steady positions - a steady level of $48 \%$.

Owners of a corporation, among whom the central place is taken, again, by the state, appear to be second important "recipients" of a value added. In the present research, it is offered to abstract from the personification of owners and consider them as abstract entities with well-known interest in the form of maximising their share of a value added, i.e. their profit. During the whole considered period, despite a presence of some volatility, it is possible to notice a steady growth of owners' share. Beginning with $27 \%$ in 2004-2005, the owners' share fell just a little short of $40 \%$ in 2010 and 2011, while it made $33.8 \%$ in 2012 (Fig. 6). Simultaneously, one should note an insignificant growth of a share of part of the value added, consumed by owners, almost within the limits of a statistical error. However, in absolute terms, the sum of payments of dividends increased by 5 times - from 28.2 to 141.8 milliard rubles.

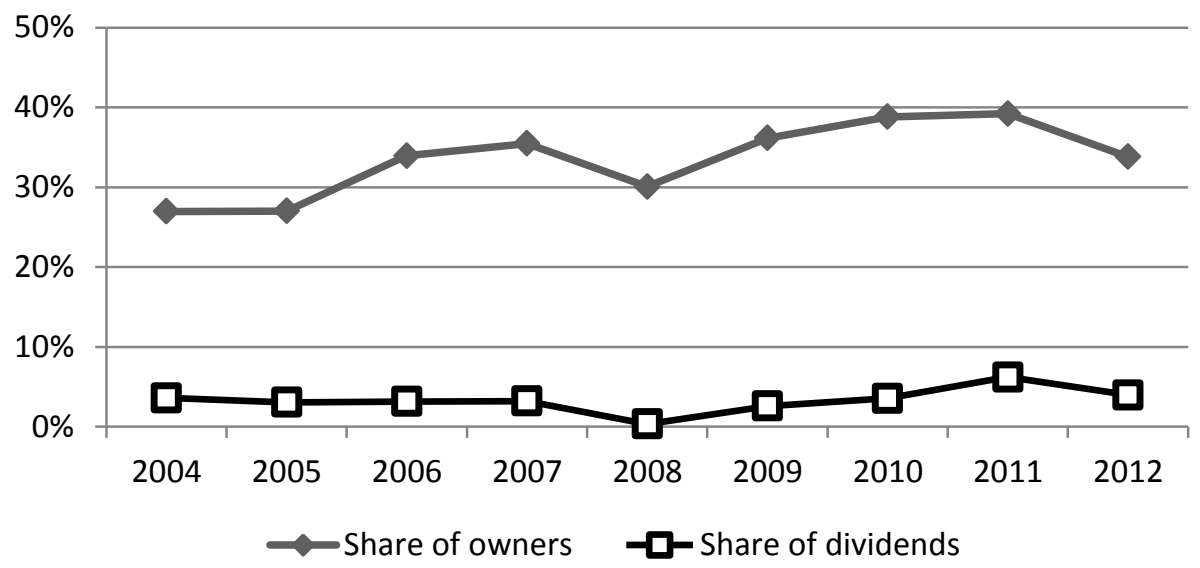

Figure 4. The dynamics of the share of the Gazprom Corporation's value added, distributed in favour of owners in 2004-2012

In addition, it should be noted that a consideration of a share received by the state as an owner of the Gazprom Corporation (50\%), enables one to correct the above-given assessment of the share of the value added, appropriated by the state. In the aggregate, taxes, customs payments and a profit of a corporation permit the latter to derive up to $70 \%$ of a cumulative value added. And this share is practically invariable.

Employees of a corporation are a third important entity from the viewpoint of the appropriation of a value added. Their share is steadily reducing during the period from 2004 (13.8\%) to 2012 (10.4\%). In this respect, the share of managing directors increased from $0.028 \%$ (in 2004) to $0.040 \%$ in 2012 with an equal steadiness (Fig. 7). At the same time, an observed growth of an average salary is a consequence of both a reduction in the number of the employed, and a growth of the value added in absolute terms. The exposed reduction of a share of the employees in the gross value added of the Gazprom Corporation testifies to an alienation of the employees from the Corporation.

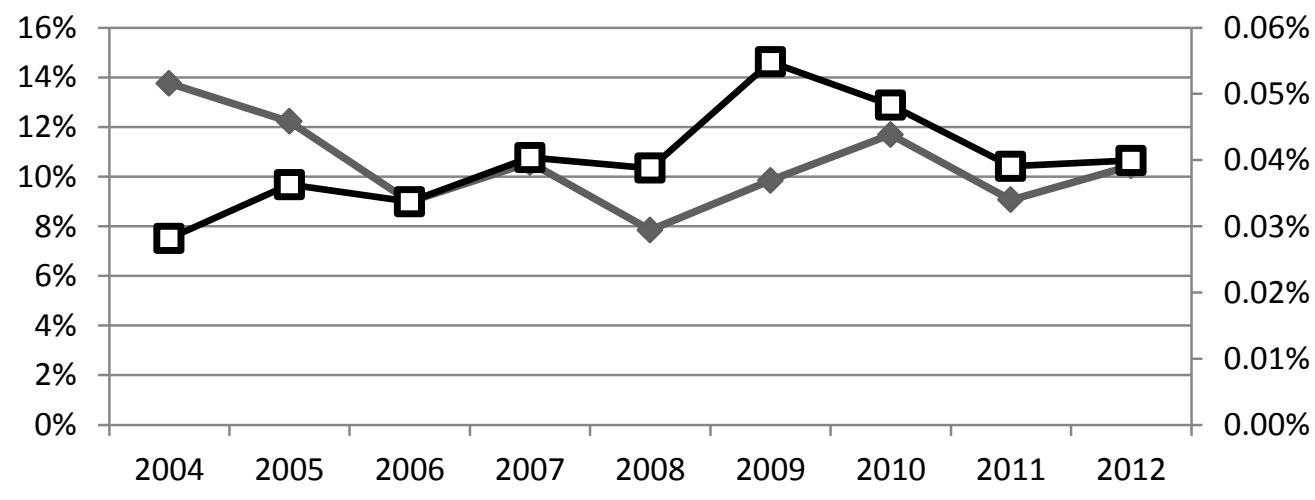

$\neg$ Share of workers $\quad-$ Share of the Board of Directors (right axis)

Figure 5. The dynamics of the share of employees in the structure of the value added of the Gazprom Corporation in 2004-2012 
It is fair to say that "a peak" of the share of the value added at the disposal of managing directors already passed (in 2009), and a steady decrease of this indicator (from $0.055 \%$ to $0.040 \%$ ) has been observed for 3 years. In absolute terms, the remuneration of managing directors grew during the considered period - from 0.22 to 1.43 milliard rubles a year. In this regard, in no one of the considered periods was a decrease of the sum of the remuneration observed, whereas in the recessionary 2009 a growth was by $20 \%$. In addition, it should be noted that distinctions in the dynamics of shares of the remuneration of employees and managing directors permits to formulate a hypothesis of a strengthening of differentiation in payment for labour.

The smallest share (about 3\%) falls on investors' share (primarily, banks), and in the "recessionary" years of 2008-2009 their share increased by more than twice, and then - it decreased again to 2.6\%. The Gazprom Corporation do not stand in a great need of the use of loan capital (about $12.5 \%$ of the whole capital of the Corporation fell on its share in 2012, and in comparison with 2011 there occurs a decrease in this share).

\section{Conclusions and Prospect Research}

The presented conclusions only manifest the first view of the structure and distribution of the value added in the Gazprom Corporation. A more detailed analysis will permit to reveal in-depth contradictions between interests of various groups of the Corporation's entities, to understand the hidden mechanisms of the distribution of the value added as an objective characteristic of such a many-sided phenomenon in modern economy as the Gazprom Corporation. Moreover, the share of the value added at the disposal of one or another entity can show the real distribution of property rights better than other indicators. Proceeding from this statement, Gazprom belongs to the state in a scope of $70.05 \%$; to private owners and institutional investors in a scope of $16.90 \%$; to employees in a scope of $10.39 \%$; to banks and other investors in a scope of $2.61 \%$; and to top managers (managing directors) in a scope of remaining $0.05 \%$. At first sight, a conclusion that employees' rights of the property of the Corporation by 200 times exceed those of its management, is absurd, but one should not forget that (a) the power of employees is diffused between them, and on the average less rights fall on one employee than on one top manager; and (b) theoretically, if one assumes an existence of the employees' integrated "intelligence" and their integrated volition, then, certainly, such intelligence and such volition will possess much bigger rights to the Corporation than its top management.

Some important advantages of the value-added-based indicator for such an investigation are its absence in data of accounting reports, and a present-day inattention to it on the part of investors, owners and other "controllers". For this reason, the calculation of the indicator in the course of an independent investigation gives the most objective picture which is not veiled by an aspiration for achieving a requisite result. In our opinion, this indicator should occupy a worthy place in scientific studies and expert estimates of the activity efficiency of managing entities.

\section{Acknowledgement}

The publication was prepared as part of a research project supported by RSF (application \# 14-18-02508) and RHSF \# 14-02-00316

\section{Reference}

- Biddle \& Bowen \& Wallace, 1999. Evidence on EVA. Journal of Applied Corporate Finance, 12(2).

- Fernandez, 2013. Three Residual Income Valuation Methods and Discounted Cash Flow Valuation (DOI: http://dx.doi.org/10.2139/ssrn.296945)

- Gazprom, 2013a The consolidated financial statements prepared in accordance with International Financial Reporting Standards (IFRS)of GAZPROM corporation for 2004, 2005, 2006, 2007, 2008, 2009, 2010, 2011, 2012 years. Retrieved from http://www.gazprom.ru/investors/reports/

- Gazprom, 2013b GAZPROM corporation: Quarterly report for Q1 2005, 2006, 2007, 2008, 2009, 2010, 2011, 2012, 2013 years. Retrieved from http://www.gazprom.ru/f/posts/52/479048/gazprom-emitent-report1q-2013.pdf)

- Krishnamurthy \& Deenadayalan \& Srilatha, 2011. Gandhian Marxism with Ethics and Values of Sustainability Coexisting with Capitalism: Lal Salam to Governance of Dayakar Reddy. International Conference on Entrepreneurship and New Venture Creation: International Models and Benchmarks, Indian Institute of Management Bangalore, India.

- Marginson, 1998. Value creation in the production of services: a note on Marx, Cambridge Journal of Economics, 22(5), pp. 573-585.

- Pletnev, D., 2013. Dobavlennaya stoimost' korporatsii: teoriya i rossiyskaya praktika [The added value of a corporation: theory and Russian practice]. Economics Theory Journal, Vol. 1, p. 131-147 
- Stiglitz J., Amartya Sen and Jean-Paul Fitoussi The Measurement of Economic Performance and Social Progress Revisited - Reflections and Overview, September, 16, 2009 (режим доступа: http://www.stiglitzsen-fitoussi.fr/documents/overview-eng.pdf)

- Velez-Pareja, 2001. Value Creation and its Measurement: A Critical Look at EVA. Cuadernos de Administración, 22, pp. 7-31.

- Weissenrieder, 1997. Value Based Management: Economic Value Added or Cash Value Added? FWC AB Study, Vol.1997:3. (DOI: http://dx.doi.org/10.2139/ssrn.156288) 